\title{
Comparison of Using Different Kinds of Traffic Data in Best Route Analysis Based on GIS
}

\section{Klemen Prah \\ Assistant Professor University of Maribor Faculty of Logistics \\ Slovenia \\ Gregor Štrubelj \\ Teaching Assistant University of Maribor \\ Faculty of Logistics \\ Slovenia}

Geographic information systems (GIS) represent a sophisticated tool in transportation network analysis. It is very important how transportation network is modelled regarding traffic data. Usually, fixed travel speed data is used, but due to advancements in information and communication technologies (ICTS) and location-aware technologies (LATs), it is now possible to collect large amounts of mobility and activity data in real-time. The aim of the paper is to make a comparison between different types of best route analysis regarding different travel speed information: fixed travel speed, historical traffic, and live traffic. This finding would not be important only for best route analysis but also for other types of network analyses. First, we distinguish between different kinds of travel speed information, then we present our practical work of creating three different types of network models according to different types of traffic speed data, and finally we perform best route analysis along the above models and compare the results.

Keywords: traffic data, live traffic, transportation network analysis, best route analysis, geographic information systems (GIS).

\section{INTRODUCTION}

Transport represents one of the most important human activities worldwide [1] and has an important role in supply chain. We can recognize some major global trends shaping 21 st century transportation. The increasing globalisation of economies and societies pushes for faster and more efficient transportations systems, and in parallel we are witnessing the continuing motorization of world population [2]. For these reasons we need sophisticated transportation management strategies, contributing to sustainable world. This management should be supported by sophisticated transportation studies, where analysis plays a critical role [3]. An advanced tool in transportation analyses represent geographic information systems (GIS). Namely, GIS have developed a number of spatial analysis tools and incorporated some transportation analysis functions into GIS software packages to support transportation and other application needs [2]. In addition to analysis, GIS software is also used for representation, management and visualization of geographic data.

Network analysis is a topic among transportation analyse that has been widely pursued [2]. GIS allow us to solve common network problems, including finding the best route, finding the closest facility, identifying a service area around a location, servicing a set of orders with a fleet of vehicles, or choosing the best facilities to open or close [4]. The heart of any GIS analysis in

Received: June 2017, Accepted: June 2018

Correspondence to: doc. dr. Klemen Prah

University of Maribor, Faculty of Logistics,

Mariborska cesta 7, 3000 Celje, Slovenija

E-mail: klemen.prah@um.si

doi:10.5937/fmet1804668P

(C) Faculty of Mechanical Engineering, Belgrade. All rights reserved transportation is georeferenced transportation database focused on transportation network. Nodes in such network correspond to intersections, junctions, stops or switching points, and arcs represent infrastructure and/or services between nodes [2].

What matters in network analysis is how transportation network is modelled regarding traffic data. Traffic data provides information, among others, how travel speeds on specific road segments change over time. This is important in network analysis because traffic affects travel times, which in turn affect results ("What is traffic data?," 2016). Travel time information based on ITS can be divided into three categories: historical, real time, and predicted [5]. In addition, there is a simpler option to model the transportation network without traffic data, only on the basis of fixed travel speed information. Transportation network analysis problems can be defined either as static or dynamic. If the problem calls for the determination of a set of preplanned routes that are not reoptimized and are computed from inputs that do not evolve in real time, the problem is static. Conversely, if the routes are reoptimized, or if the output is a policy that prescribes how the routes should evolve as a function of those inputs that evolve in real time, then the problem is dynamic [6].

Fixed travel speed data was often used in the transportation network analysis till now. But due to advancements in information and communication technologies (ICTs) and location-aware technologies (LATs), it is now possible to collect large amounts of mobility and activity data from a wide range of mobile sensors in real-time or near-real-time at high spatial and temporal granularity [2]. These datasets have potentials of providing us with opportunities to gain insight into mobility patterns and human behaviours that could be 
useful in transportation planning, operation, maintenance and policy making [7]. Consequently it is no longer sufficient to represent different datasets as a static snapshot GIS map layers [2]. Therefore we strive to perform transportation network analysis using near-real time traffic data.

The aim of the research is to make a comparison between the following types of best route analysis regarding travel speed information: analysis with fixed travel speed information, analysis with daily travel speed profiles (historical traffic), and analysis with live traffic data. The question is what are the differences in travel time when using different travel speed information? Are these differences significant (amounting to 20 percent or more) or insignificant? This finding would not be important only for best route analysis but also for other types of network analysis like identifying a service area around a location, servicing a set of orders with a fleet of vehicles, etc.

The research is focused on the city of Celje with its surroundings. The structure of the paper is as follows. First we distinguish between different kinds of travel speed information: fixed travel speed, historical traffic, and live traffic. Then we present our practical work of creation of three different types of network models according to different types of traffic speed data. Finally we perform best route analysis according to mentioned models and compare the results.

\section{TRAVEL SPEED INFORMATION}

Information on traffic conditions is widely available nowadays. It is integrated in finding route analysis within different web map browsers, for example HERE Maps [8]. But in order to analyze more traffic networks, we need more sophisticated GIS software, like ArcGIS $[8,10$. In such analysis, a transportation network can be modelled using historical or live traffic data or even only fixed travel speeds.

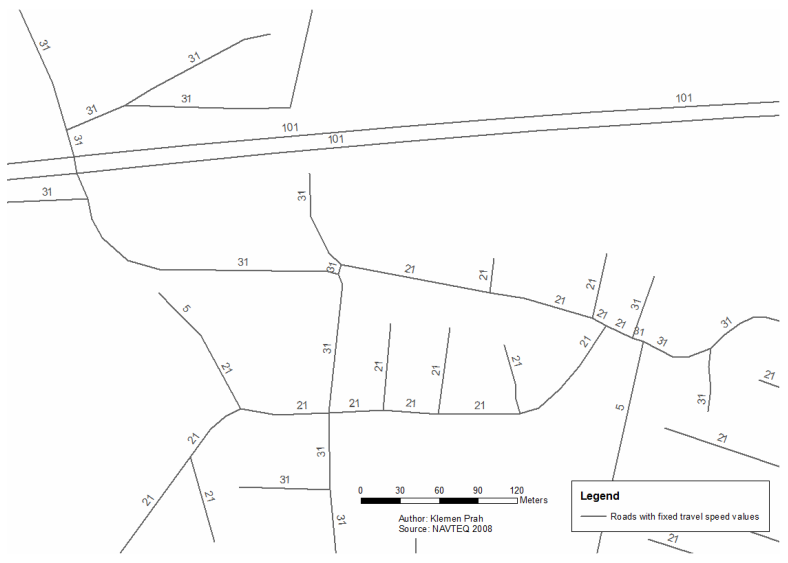

Figure 1. Roads with fixed travel speed values in northern part of Celje city. Highway with highest speed values in the upper part is crossing residential neighbourhoods.

\subsection{Fixed travel speed}

Fixed travel speed values for each road segment can be derived from the field Speed Category [11]. This field classifies the general speed trend of a road based on posted or legal speed and is provided to enhance route calculation and the timing of route guidance. Speed Category values represent the combination of several factors besides legal speed limit (e.g., physical restrictions or access characteristics). The field Speed Category contains following categories of ranges of values: <11 KPH, 11-30 KPH, 31-50 KPH, 51-70 KPH and so on. For the travel speed value of a road segment we take the lowest value of the field Speed Category, $11,31,51 \mathrm{KPH}$ and so on. This is because of possible obstacles that could slow the traffic. For the lowest Speed Category we take the middle travel speed value of $5 \mathrm{KPH}$. An example of fixed travel speed values for a selected area in Celje is presented in Figure 1.

\subsection{Historical traffic}

Historical travel times provide data relating to changes in travel times in the past [5]. Historical traffic is based on averages and is good for providing an estimate of what traffic would look like for a given time of the day and day of the week [12]. To create historical traffic data for the service, a week is broken into intervals, for example five-minute, travel speeds are collected for each interval over several weeks, and then the speeds for each interval are averaged [12]. Thus, a daily profile of travel speed or travel time is assigned to each road segment. One road segment can have different profiles on different days of the week. As long as the data is reliable, performing a network analysis using the historical traffic model will tend to return much more accurate results than those returned using a single travel cost irrespective of time or day of the week [13]. Even more, we can assume that the time we actually spend driving is likely to be less if traffic patterns are taken into account [14].

\subsection{Live traffic}

Live traffic or real-time traffic represents dynamic information relating to changes in travel times at the present time [5]. Below we summarize some basic characteristics of the live traffic data and the model [13]. Current travel times can deviate considerably from the norm because of large crowds, accidents and other events. When we solve a network analysis whose results will be implemented immediately or almost immediately (i.e. for emergency vehicles), using live traffic will tend to improve results, even over those created with historical traffic. With the live traffic model, data providers measure current speeds using a number of sources, such as GPS receivers in vehicles and speed sensors on roads. As the information technology infrastructure becomes more sophisticated, more accurate real-time information about traffic incidents and traffic congestion will be available at all times [15]. Of course, a single snapshot of live traffic used for network analysis purposes would not be entirely helpful because traversing a network takes time, which means an analysis extends into the future, and traffic patterns change with time. This is one reason data providers also process live traffic data to make travel-speed predictions of a given depth, such as for the next 12 hours. This way, network analysis can start its network traversal from one point using live traffic, then 
switch to predicted speeds as the traversal extends outward. As the network analysis queries edges for travel speeds that span farther into the future, speed projections become inherently less reliable - that is, the probability of other events occurring and affecting traffic increases. Once the prediction depth is reached, network analysis falls back to historical traffic speeds. From the above mentioned it can be discerned that, although historical traffic can be configured without live traffic, live traffic must be configured along with historical traffic. Especially live traffic is used to see traffic conditions and to perform time-dependent network analysis [13].

\section{PRACTICAL WORK - PREPARING A TRANSPORTATION NETWORK MODEL}

To perform transportation network analysis we need to create transportation network model first. According to the type of traffic data, we can distinguish between three different transportation network models. The first is based on fixed travel speeds (no traffic data), the second is based on historical traffic supported within web application ArcGIS Online [10], and the third is based on Traffic Agent system in Slovenia.

\subsection{Transportation network model based on fixed travel speeds}

The basis for the model represents a network dataset, which is a collection of topologically connected network elements (edges, junctions, and turns) and is used to model traffic flow systems [16]. In our model, the information of fixed travel speeds is built in edge source layer "Streets" [11]. It appears as "Speed" field and is derived from the Speed Category field. The other characteristics of the model are as follows. Connectivity policy is "End Point", which means that an edge may only connect to another edge at its endpoints [17]. This also means that any street going under the bridges will not be connected to the bridge [18]. The elevations are modelled by two attributes "From Z-Level" and "To ZLevel". The model has various costs, descriptors, restrictions, and hierarchy attributes [19]. Cost attributes are Meters and Minutes of which the second means fixed travel times for all road segments and is calculated according to attributes Meters and Speed. Restriction attributes are three. The attribute Avoid Unpaved Roads has value Avoid: Medium, while attributes Oneway and Restriction Auto have value Prohibited. The Hierarchy attribute is based on the field Functional Class which defines hierarchical network. U-turns are allowed only at intersections and dead ends.

\subsection{Transportation network model based on live traffic within ArcGIS Online}

ArcGIS Online is a complete, cloud-based mapping platform [10], which lets us view historical, live, and predicted traffic conditions. The map shows current traffic as a blend of live and typical information. Live speeds are used wherever available and are established from real-time sensor readings. Typical speeds come from a record of average speeds, which are collected over several weeks within the last year or so [13]. The platform allows us to solve different types of transportation network problems, but without the need to create a network dataset. In our model we used following settings. We allowed U-turns only at intersections and dead ends. We used hierarchy which classifies network edges into a given number of levels. Performing network analysis using a hierarchy makes use of a heuristic that reduces the computation time by limiting the search mostly to the higher levels of the hierarchy. It is true that this may lead to a solution with a slightly higher cost than if we were to solve the same problem without using the hierarchy [20]. From restriction attributes we used Avoid Unpaved Roads with parameter value Avoid: High.

\subsection{Transportation network model based on live traffic via Traffic Agent}

In Slovenia, a system called Traffic Agent [21] was established for automatic traffic monitoring and reporting on traffic state. Application works through 746 traffic counters, series QLTC, and represents an upgraded basic function of vehicle counting and classification. Modern telecommunications and information technology enables publishing of traffic data in real time on the worldwide web (Figure 2). The definition of a traffic state for each driving lane individually is based on measured values in a selected time interval according to:

- average speed of vehicles,

- $\quad$ average time between driving vehicles, and

- occupancy of the carriageway, given in promilles, as a ratio between the occupancy time of measuring sensors and time of interval observation.

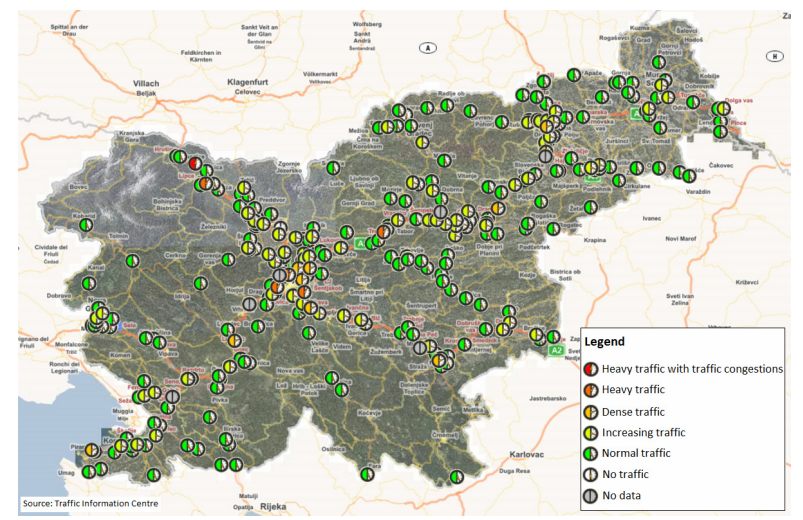

Figure 2: Traffic state in Slovenia on 22nd of April 2016, at 9.20 a.m. based on Traffic Agent system [22].

Data was made available at request as a live geoRSS feed that updates every five minutes. Technically, we were given access to a file server with the appropriate XML files by Slovenian Infrastructure Agency and then set up the feed ourselves. The feed can be imported to ArcGIS as a point layer. For the data to be used in route analysis, it has to be of the right form - as attributes of the road network, which is represented as a line layer. One could assign the values of measuring points from the live feed to the surrounding road sections through spatial joining. That leaves the majority of road sections without values. The model would need some kind of interpolation to fill out the remaining sections. At this moment it is not complete as we were short on time and leave it for future work. 


\section{BEST ROUTE ANALYSIS}

Below we present the results of best route analyses, based on two different types of transportation network models, associated with different types of traffic information. The first analysis is based on fixed travel speed information, and the second on traffic information within ArcGIS Online platform. We compare the travel times between these two.

As mentioned above, the study area is the city of Celje with its surroundings. The problem is to find best routes from the fire station, which is located in the centre of the city, to four fire incidents, which are located in the city or its surroundings (Figure 3 ). The first incident is in Tremerje, south from Celje, the second one is in Medlog west from Celje, the third in Hudinja in the northern part of Celje, and the fourth in Teharje, east from Celje. The incidents are independent of each other. We are looking for the best routes - best travel times from the fire station to each incident.

We calculated best routes with ArcGIS software and its extension Network Analyst [9]. The results are presented in Figure 3 and Table 1. Best route to Tremerje takes 9.2 minutes, to Medlog 5.27 minutes, to Hudinja 3.58 minutes and to Teharje 5.06 minutes.

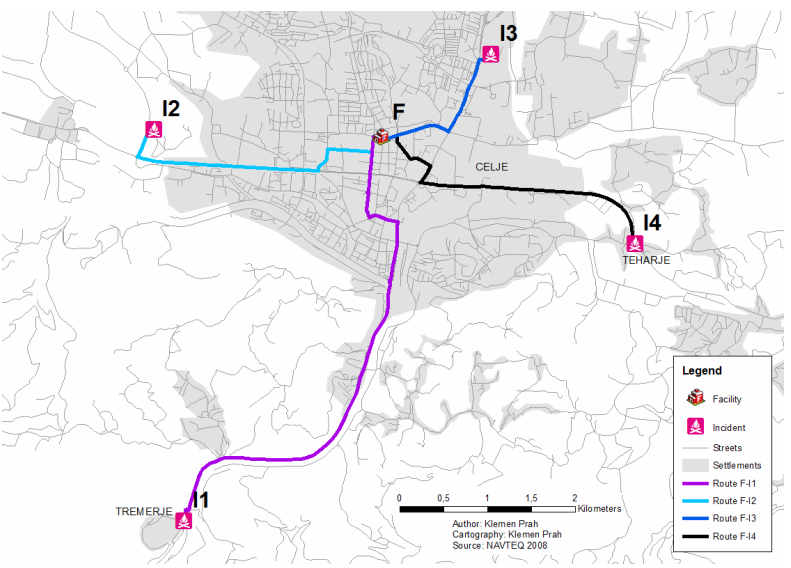

Figure 3. Best routes from the fire station to four incidents according to fixed travel speed information.

Table 1. Travel times for best routes from the fire station to incidents, based on fixed travel speed information.

\begin{tabular}{|c|c|}
\hline Origin and destinations & Travel time (min) \\
\hline F-11 & 9.20 \\
\hline F-12 & 5.27 \\
\hline F-13 & 3.58 \\
\hline F-14 & 5.06 \\
\hline
\end{tabular}

The next analysis is based on traffic information within ArcGIS Online platform. The analysis was performed for Monday 4th of April 2016. We took twelve different times during that day, starting at 3 a.m. and finishing at 11 p.m. (Table 2). Best routes are presented on Figure 4. Travel times vary during the day. All four routes have the shortest travel time at 3:15 a.m. The longest travel time differs between routes. On the route to Tremerje (F-I1), the peak is at 10:00 a.m. and at noon. The peak is also at noon on the route to Medlog (F-I2). The longest travel time to the remaining two destinations - Hudinja and Teharje - is at 15:20, when people are returning from work.

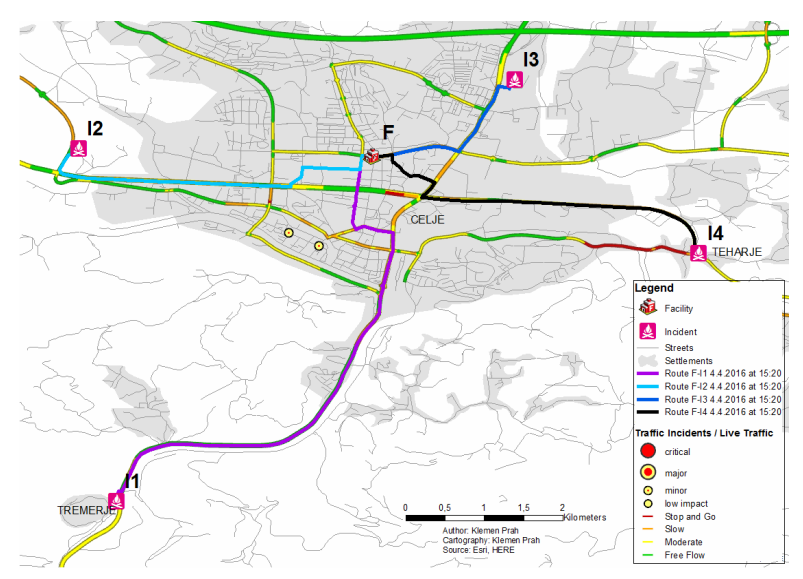

Figure 4. Best routes from the fire station to four incidents according to traffic information within ArcGIS Online platform.

Table 2. Travel times for best routes from the fire station to incidents on different times of the day, based on traffic information within ArcGIS Online.

\begin{tabular}{|c|c|c|c|c|}
\hline Time & $\begin{array}{c}\text { Route } \\
\text { F-I1 }\end{array}$ & $\begin{array}{c}\text { Route } \\
\text { F-I2 }\end{array}$ & $\begin{array}{c}\text { Route } \\
\text { F-I3 }\end{array}$ & $\begin{array}{c}\text { Route } \\
\text { F-I4 }\end{array}$ \\
\hline $03: 00$ & 7.97 & 4.35 & 3.3 & 5.05 \\
\hline $06: 30$ & 8.32 & 4.5 & 3.39 & 5.37 \\
\hline $07: 30$ & 8.99 & 4.88 & 3.64 & 5.9 \\
\hline $08: 30$ & 9.94 & 5.46 & 3.96 & 6.51 \\
\hline $10: 00$ & 10.1 & 5.57 & 4.04 & 6.63 \\
\hline $12: 00$ & 10.1 & 5.63 & 4.08 & 6.62 \\
\hline $15: 00$ & 10.07 & 5.62 & 4.08 & 6.57 \\
\hline $15: 20$ & 9.92 & 5.33 & 4.45 & 7.29 \\
\hline $18: 00$ & 9.98 & 5.59 & 4.04 & 6.47 \\
\hline $20: 00$ & 9.59 & 5.4 & 3.84 & 6.09 \\
\hline $22: 00$ & 9.23 & 5.19 & 3.72 & 5.83 \\
\hline $23: 00$ & 8.54 & 4.71 & 3.47 & 5.36 \\
\hline Average & 9.40 & 5.19 & 3.83 & 6.14 \\
\hline
\end{tabular}

\subsection{Transportation network model based on fixed travel speeds}

Below we compare travel times for both best route analyses, those with static and those with dynamic travel speed information (Table 3 and Figures 5-8). We can recognize that the routes F-I1, F-I3 and F-I4 have longer average dynamic travel times. The biggest difference is 1.08 minutes for route F-I4. The average dynamic travel time is shorter only for route F-I2, and even there the difference is only 0.08 minutes.

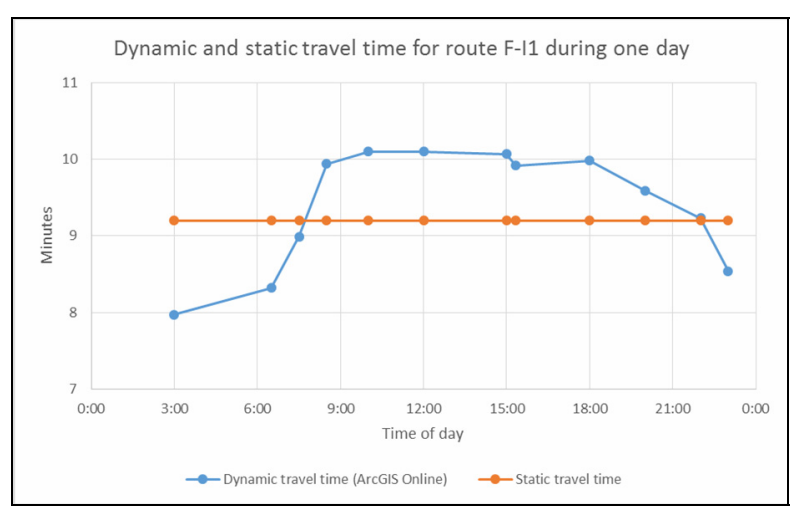

Figure 5: Comparison of static and dynamic travel time for route F-I1 during one day. 
The biggest difference between minimum and maximum dynamic travel time is for route F-I4, accounting 2.24 minutes. The difference between minimum dynamic travel time and static travel time is the biggest for route F-I1 which accounts for 1.23 minutes. The same parameter for route F-I4 accounts for almost zero. The biggest difference between maximum dynamic travel time and static travel time is for route F-I4 and accounts for 2.23 minutes.

Table 3: Comparison of travel times between two types of best route analyses: one based on statistic and another on dynamic speed information.

\begin{tabular}{|l|c|c|c|c|}
\hline & F-I1 & F-I2 & F-I3 & F-I4 \\
\hline static travel time & 9.2 & 5.27 & 3.58 & 5.06 \\
\hline average dynamic travel time & 9.4 & 5.19 & 3.83 & 6.14 \\
\hline $\begin{array}{l}\text { difference between static and } \\
\text { average dynamic travel time }\end{array}$ & 0.2 & -.08 & 0.25 & 1.08 \\
\hline $\begin{array}{l}\text { minimum dynamic travel time } \\
\text { maximum dynamic travel time }\end{array}$ & 7.97 & 4.35 & 3.3 & 5.05 \\
\hline $\begin{array}{l}\text { difference between min and max } \\
\text { dynamic travel time }\end{array}$ & 2.13 & 1.28 & 1.15 & 2.24 \\
\hline $\begin{array}{l}\text { difference between min dynamic } \\
\text { and static travel time }\end{array}$ & 1.23 & 0.92 & 0.28 & 0.01 \\
\hline $\begin{array}{l}\text { difference between max } \\
\text { dynamic and static travel time }\end{array}$ & 0.9 & 0.36 & 0.87 & 2.23 \\
\hline
\end{tabular}

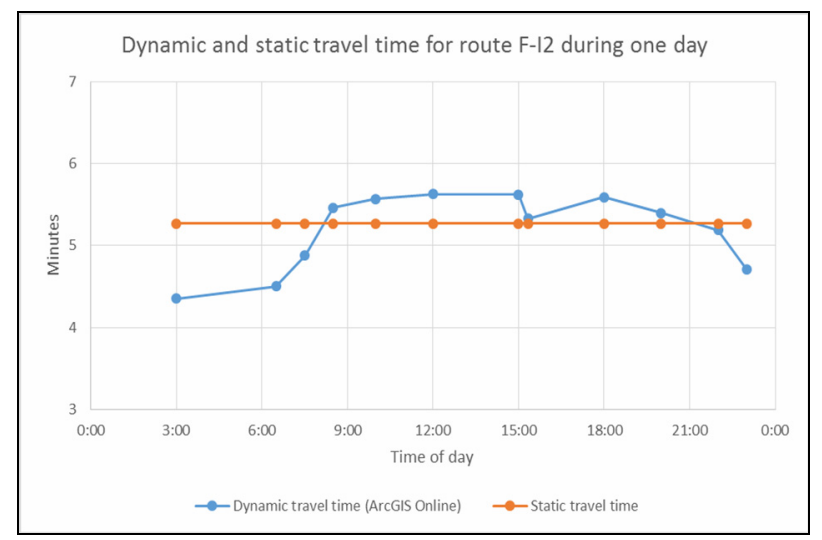

Figure 6: Comparison of static and dynamic travel time for route F-12 during one day.

\section{CONCLUSION}

Traffic data provides information about how travel speeds on specific road segments change over time. It is important in network analysis because traffic affects travel times, which in turn affect results.

So far, we have mainly used constant values of speed categories for individual road sections in GIS analysis.

With the rapid development of information and communication technologies (ICTs), dynamic information on traffic conditions is becoming more and more available.

When we solve a network analysis whose results will be implemented immediately or almost immediately, using live traffic will tend to improve results. Therefore the dynamic speed information is necessary when determining the shortest path for urgent vehicles, food delivery, express mail delivery and so on. One or two minutes saved is of great importance, especially in the case of urgent vehicles.

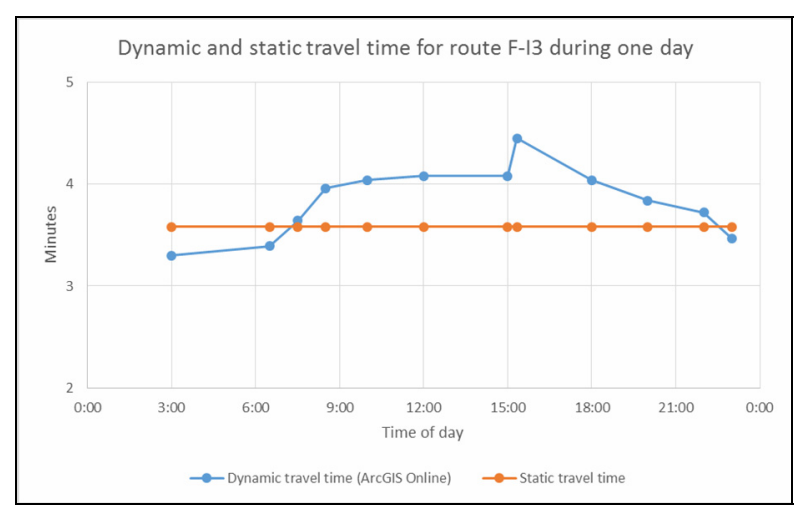

Figure 7: Comparison of static and dynamic travel time for route F-I3 during one day.

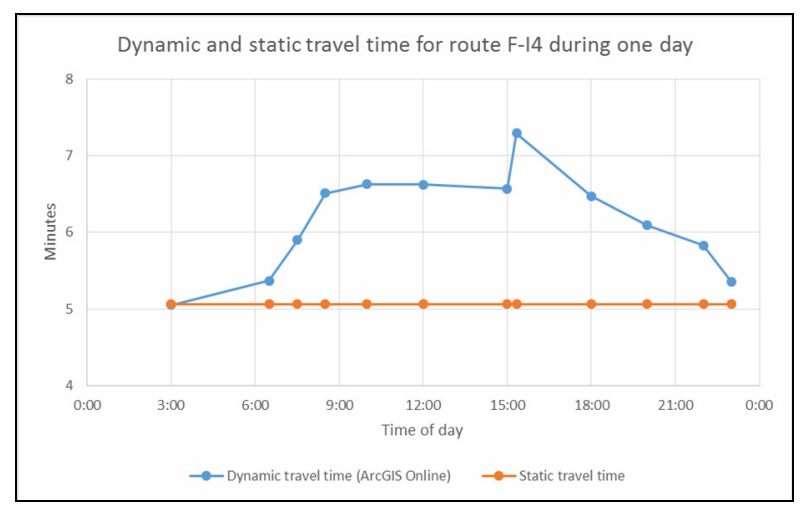

Figure 8: Comparison of static and dynamic travel time for route F-14 during one day.

On the contrary, static speed information is good enough, when we solve a network analysis, whose results will not be implemented immediately. Such are examples of solving vehicle routing problem (VRP) like waste collection, school bus routing, delivery of goods, etc.

Can live traffic/speed information produce better results than fixed speed information? In our case we cannot say that the time we spend driving is shorter if traffic patterns are taken into account. Namely we can recognize that the routes F-I1, F-I3 and F-I4 have longer average dynamic travel times than static times. The biggest difference is 1.08 minutes for route F-I4. The average dynamic travel time is shorter than static travel time only for route F-I2, and even there the difference is only 0.08 minutes. Dynamic and static travel time are most similar between 7:30 and 8:30 a.m. and around 22:00 p.m. (for routes F-I1, F-I2, F-I3). During the day dynamic travel time is longer than static travel time. The biggest difference between maximum dynamic travel time and static travel time is 2.23 minutes and is for route F-I4 and for time 15:20 p.m. The biggest difference between minimum dynamic travel time and static travel time is 1.32 minutes and is for route F-I1 and for time in the middle of the night.

In our case, travel time around working hours is higher and lower during night hours. As expected, the average dynamic times do not differ much from the average static times. They do tend to be higher which can be partly explained by the ever growing number of registered road vehicles. Data for our static transportation network dates from 2008 and according to Statistical Office RS, the growth rate of registered road vehicles between year 2008 and 2014 (no data for 2015 yet) is 5.14\% [23]. 
It makes sense to take dynamic properties of traffic into account as they could considerably cut travel time. Namely, it is easier to plan the trip if we consider traffic fluctuations during the day. In other words, it is easier to decide when to go on the road not to run into congestion.

Enormous amounts of data are collected every second around the world, much of it is even in public domain, like in our case. The real challenge is to use available data in a meaningful way. Finalizing the implementation of the described live traffic model will aim to answer the call.

\section{REFERENCES}

[1] J.-P. Rodrigue, B. Slack, and C. Comtois, The geography of transport systems. London; New York: Routledge, 2013., 2013.

[2] H. J. ( 1 ) Miller and S.-L. ( 2 ) Shaw, Geographic information systems for transportation in the $21 \mathrm{st}$ century, Geogr. Compass, vol. 9, no. 4, pp. 180 189, 012015.

[3] H. J. ( 1 ) Miller and S.-L. ( 2 ) Shaw, Geographic information systems for transportation: principles and applications. Oxford, 2001.

[4] Types of network analysis layers, Feb. 2016. http://desktop.arcgis.com/en/arcmap/10.3/guidebooks/extensions/network-analyst/types-ofnetwork-analyses.htm

[5] E. Taniguchi, H. Shimamoto, Intelligent transportation system based dynamic vehicle routing and scheduling with variable travel times, Transp. Res. Part C, vol. 2004, no. 12, 2004.

[6] H. N. Psaraftis, M. Wen, C. A. Kontovas, Dynamic vehicle routing problems: Three decades and counting, Networks, vol. 67, no. 1, pp. 3-31, 012016.

[7] S.-L. Shaw, Guest editorial: Geographic informaion systems for transportation - An introduction, $J$. Transp. Geogr., vol. 19, pp. 377-378, Jan. 2011.

[8] HERE Maps. 2016. URL: https://maps.here.com/

[9] ArcGIS for Desktop. Redlands: Environmental Systems Research Institute, 2014.

[10]ArcGIS Online. Environmental Systems Research Institute.

[11]NAVTEQ's NAVSTREETS Street Data, Reference Manual v3.0. Chicago, Illinois: NAVTEQ, 2008.

[12] Consuming the traffic service using ArcMap, Apr. 2016. http://resources.arcgis.com/en/help/main/0.2/ ndex.html\#//0047000001v1000000

[13] What is traffic data?, Feb.2016. http://desktop.rcgis. om/en/arcmap/10.3/guide-books/extensions/ network-analyst/traffic-what-is-traffic-data.htm

[14] Historical traffic, 2016. http://desktop.arcgis. com/ en/arcmap/10.3/guide-books/extensions/networkanalyst/traffic-historical-10-1-and-later.htm

[15] S. Panahi and M. R. Delavar, Dynamic Shortest Path in Ambulance Routing Based on GIS., Int. J. Geoinformatics, vol. 5, no. 1, pp.13-19, Mar. 2009.
[16] Network dataset, GIS Dictionary. 25-Apr-2016. http://support.esri.com/en/knowledgebase/GISDicti onary/search

[17] Endpoint connectivity, GIS Dictionary. Esri, 20Apr-2016. URL: http://support.esri.com/en/ knowledgebase/GISDictionary/term/endpoint $\% 20 \mathrm{c}$ onnectivity

[18] Understanding connectivity, April 2016. URL: http://webhelp.esri.com/arcgisdesktop/9.3/index.cf $\mathrm{m}$ ?TopicName=Understanding_connectivity

[19] Understanding network attributes, April 2016. http://desktop.arcgis.com/en/arcmap/10.3/guidebooks/extensions/network-analyst/understandingnetwork-attributes.htm

[20] About network analysis with hierarchy, April 2016. http://desktop.arcgis.com/en/arcmap/latest/extensio ns/network-analyst/network-analysis-withhierarchy.htm

[21] Traffic Agent System.

[22] Traffic Information Centre, April 2016. http:// www.promet.si/portal/en/1 traffic-conditions.aspx

[23] Statistical Office RS, May 2016. URL: http://www.stat.si/StatWeb/en/home

\section{ПОРЕЪЕЊЕ КОРИШТЕЊА РАЗЛИЧИТИХ ВРСТА ПОДАТАКА О САОБРАЋАЈУ У АНАЛИЗИ НАЈБОЉЕГ ПУТА ПРИМЕНОМ ГЕОГРАФСКОГ ИНФОРМАЦИОНОГ СИСТЕМА}

\section{К. Прах, Г. Штрубељ}

Географски информацини систем (ГИС) представља софистицирану алатку за анализу транспортних мрежа. Моделирање транспортне мреже на основу података о саобраћају је од великог значаја. Обично се користе подаци о фиксној брзини возила, али захваљујући напретку у области информационих и комуникационих технологија и технологија о познавању информација о локацији сада је могуће прикупити велику количину података о мобилности и активности саобраћајау реалном времену. Циљ рада је био да се упореде анализе различитих врста најбољег пута с аспекта података о различитој брзини саобраћаја: кретање фиксном брзином, кретање у прошлости и кретање у реалном времену. Резултат истраживања не би био од значаја само за анализу најбољег пута већ и за друге врсте анализа транспортних мрежа.

Приказали смо разлику између података о различитим брзинама кретања возила, практичан начин израдетри типа модела транспортних мрежа на основу података о различитим брзинама кретања возила и на крају смо извршили анализу најбољег пута према датим моделима и упоредили добијене резултате. 